\title{
EFFECT OF AIR INLET DUCT FEATURES AND GRATER THICKNESS ON COOKING BANANA DRYING CHARACTERISTICS USING ACTIVE INDIRECT MODE SOLAR DRYER
}

\author{
P. J. Etim ${ }^{1, *}$, A. B. Eke ${ }^{2}$ and K. J. Simonyan ${ }^{3}$ \\ 1, Dept. of Agricultural Engineering, Akwa Ibom State Univ., Mkpat-Enin, Akwa Ibom State, Nigeria. \\ 2, 3, DePT. OF AGRICULTURAL AND BIORESOURCES ENGR'G MiCHAEL OKPARA UNIVERSITY OF AGRICULTURE \\ UMUDIKE, ABIA STATE, NIGERIA. \\ E-mail addresses: ${ }^{1}$ promiseetim25@yahoo.com, ${ }^{2}$ akafav@yahoo.com, 3 omogbeka@gmail.com
}

\begin{abstract}
The effect of air inlet duct area of an active indirect mode solar dryer on drying of cooking banana was studied. The factors considered for the experiment were: air inlet duct area and grater size of the product. The factors were considered at five different levels using the Central Rotatable Composite Design. The air inlet shapes considered were: square, rectangular, circular and triangular, while the product sizes were 4, 8, 12, 16 and $20 \mathrm{~mm}$ respectively. The experimental design gave a total of 52 runs for each experiment. The experiment was replicated three times with sun drying of the product as control. Data were obtained on a two hourly interval between 8:00 am to 6:00 pm on each drying day. Drying was achieved between 9 to 26 hours of drying, as compared to the control, which was between 15 to 37 hours depending on the grater size. The dryers were able to conserve between 26.67 to $37.84 \%$ of the drying time for the products. The air inlet duct area had significant effect on the drying rate of the product at $5 \%$ level of significance.
\end{abstract}

Keywords: Air inlet, drying rate, moisture content, sun drying, cooking banana.

\section{INTRODUCTION}

Drying is the oldest method of food preservation. It involves removal of moisture from a material. Drying is the phase of post-harvest operation, during which the product is dried until it attains safe moisture level [1]. When an agricultural material is dried to a safe moisture level, the growth of bacteria, yeast and molds are minimized or completely eliminated. The shelf life of agricultural materials can be linked to the level of moisture available on the material; before, during and after drying or other post-harvest operations. Drying of food is accompanied by vapourizing the water that is contained in the food. To achieve this, the latent heat of vapourization must be known. Two basic processes that characterize the process of drying are: the transfer of heat to provide the needed latent heat of vapourization and movement of water or water vapour through the food materials and subsequent separation [8]. An indirect forced convection solar dryer was developed for Cassava in a bid to address concerns related to time of drying of cassava chip by other methods of drying [5]. Itodo, et. a/ [12] suggested that the air inlet duct area of an active solar dryer can affect the performance of the dryer. Their study recommended that studies should be carried out to examine the effect of air inlet duct area on the drying process. Cooking banana that are yellowish or brownish in colour are rich in pro-vitamin A carotenoids. New leaves develop within the plant from the ground. They grow and merge from the center. The flowers incidentally grow to banana bunch. According to the findings, there is huge demand for snacks made from cooking banana as well as plantain in the market, because of its huge nutritional value [2]. A wide range of products can be obtained from processing cooking banana, examples can be found in production of flour, banana chips, banana juice, and country wine

* Corresponding author, tel: +234 - 803-265-8283 
amongst others. A solar drying system based on the principles of convective heat flow, with use of local materials for yam chip was designed by Alonge et. al [6]. It was observed that the drying time was reduced from 52 hours for sun drying to 45 hours for solar drying of yam chip. In designing an active solar drying system for some crops. Raju, et. al [15] used $40 \mathrm{~cm}^{2}$ as air inlet duct area, while Alamu [3] used $25 \mathrm{~cm}^{2}$, although the shape of the inlet was not mentioned, but drying was reported as fairly efficient in both scenarios. Tonui, et. al [18] used air inlet spacing of $0.5 \mathrm{~m}$ with an air flow rate of $227 \mathrm{~m}^{3} / \mathrm{h}$, in designing solar grain dryer with backup heater to obtain a thermal efficiency of about $58 \%$ with average drying rate of $0.0077 \mathrm{~kg} / \mathrm{h}$. Despite variation in air inlet duct area used by many while developing solar dryers, there is no report highlighting the effect of air inlet duct area on drying rate and time taken to dry the product. This was identified as a gap the study aimed at bridging.

\section{MATERIALS AND METHODS}

The moisture content of the product was determined in three forms namely: oven drying, controlled experiment and the dryer. The moisture content (initial and final) obtained from the oven drying process served as a guide to the field experiments. The moisture content of the product to be dried (cooking banana) was determined on wet basis. A laboratory drying oven was employed for determining the moisture content of the product. Samples were weighed using an electronic weighing balance of $0.0 \mathrm{lg}$ accuracy. The oven temperature was set at a temperature recommended by ASABE [7] for fruits like banana. The average initial moisture content of the samples were determined using the relationship below [7]. This method was adopted by Alonge et al. [14], Ikejiofor and Okonkwo [10] and Onyinye et al. [14]in their respective studies.

$$
\text { M.C. }=\left(\frac{W_{w-} W_{d}}{W_{w}}\right) 100 \%
$$

Where: M.C. (wb) is Moisture content of the sample on wet basis (\%), $W_{w}$ is Initial Weight of sample ( $g$ ) and $W_{d}$ is final weight of sample $(\mathrm{g})$

The angle of tilt $(\beta)$ of a solar collector was located within Latitude $10 \circ \mathrm{N}$ from the equation 2 derived by Eke [9]:

$$
\beta=2.660+\text { Lat } \varnothing
$$

Where: $\beta$ is the angle of tilt and Lat $\varnothing$ is the latitude of the collector location, truly facing south.
The amount of moisture removed from the products was obtained as in equation (3):

$$
M_{w}=\frac{W_{w}\left(M_{i}-M_{f}\right)}{1-M_{f}}
$$

Where: $M_{w}$ is the amount of moisture removed from the products $(\mathrm{g}), M_{i}$ is initial moisture content of product (\%w.b.), $M_{f}$ is final moisture content of product (\% w.b.), $W_{w}$ is Initial total weight of product (g). The quantity of heat required to raise the temperature of the product to the surface was obtained from equation (4):

$$
\mathrm{Q}_{1}=\mathrm{WwCp} \Delta \mathrm{T}
$$

Where $\mathrm{Q}_{1}$ is Quantity of heat required to raise the temperature of the product to the surface (J), $W_{w}$ is Initial Total Weight of Products, $C_{p}$ is Specific Heat Capacity of Product $(3800 \mathrm{~J} / \mathrm{Kg}), \Delta T$ is Change in Temperature $(\mathrm{K})$.

The quantity of heat required to evaporate moisture from the product surface was obtained from equation (5):

$$
\mathrm{Q}_{2}=\mathrm{Mw} \mathrm{L}
$$

$\mathrm{Q}_{2}$ is Quantity of heat required to evaporate moisture from the product surface (J), $M_{w}$ is Amount of moisture removed from the product $(\mathrm{g}), L$ is Latent heat of vapourization $(\mathrm{J} / \mathrm{Kg})$. Total heat required to remove water from the product was as in equation (6):

$$
Q_{T}=Q_{1}+Q_{2}
$$

The area of the collector was computed from the equation (7):

$$
A_{c}=\frac{Q_{T}}{F_{R} T\left(I T_{R}-U_{L}\left(T_{c}-T_{a}\right)\right.}
$$

Where: $A_{c}$ is Solar Collector area $\left(\mathrm{m}^{2}\right), Q$ Collector useful heat gain required to dry a given quantity of agricultural product (W), $T$ is Drying time (seconds), $F_{R}$ is Collector heat removal factor (Dimensionless), $I$ is Total solar radiation incident on the dryer $\left(\mathrm{W} / \mathrm{m}^{2}\right), T_{R}$ is Cover Material Transitivity (Dimensionless), $T_{c}$ is Collector air outlet temperature $\left({ }^{\circ} \mathrm{C}\right), T_{\alpha}$ is Ambient temperature $\left({ }^{\circ} \mathrm{C}\right), U_{L}$ is Overall heat transfer coefficient $\left(\mathrm{W} / \mathrm{m}^{2}{ }^{\circ} \mathrm{C}\right)$

The drying rate of the product was computed from equation (8):

$$
M_{d r}=\frac{M_{w}}{t_{d}}
$$

Where: $M_{d r}$ is Drying rate $(\mathrm{g} / \mathrm{hr}), M_{w}$ is Mass of moisture to be removed by solar heat and $t_{d}$ is Time taken to dry the product.

The equations (1) to (8) were in consonance with what was used by Oguntola et al. [13], Raju et al. [15] and 
Sacilik [16] in designing various solar drying systems. The solar panels available for experiment were three (3) 150 Watts, 12 Volts monocrystalline solar panels, which jointly gave a total available input power of 450 Watts. Half of the available power was used to power the blowers, while the remaining $50 \%$ (225 Watts) was used to charge the 200 Ampere battery. The battery was necessary to compensate for losses and voltage drop arising from low solar intensity. Considering the amount of power available (225 Watts) and the number of dryers needed for the experiments, each individual blower required. Power required by individual dryer,

$$
P=\frac{\text { Total Power }}{\text { Number of blowers }}
$$

The total number of blowers needed for the experiment was 52 . The power required by each individual blower was:

Power required by individual dryer, $\mathrm{P}=225 / 52=4.33$ Watts/blower (Theoretical)

Two blowers close to the above were 3.6 Watts (12 Volts, 0.3 Amperes) and 7.2 Watts (24 Volts, 0.3 Amperes). It was not feasible to use the 7.2 Watts blower, since the blower had a voltage (24V), 100\% higher than what the solar panel provided (12V). However, the 3.6 Watts blower was chosen, since its voltage rating was in consonance with the rating of the solar panel $(12 \mathrm{~V})$. The power utilized by each individual dryer was computed as thus:

Power utilized by individual dryer, $\mathrm{P}=3.6 \times 52=188$ Watts.

The solar battery was deployed to compensate for the difference in power that was provided by the same solar panel and what was utilized by the blowers. The dryer was made up of the solar collector section, the drying chamber and the inlet and outlet vents, solar panels, dry cell battery and blowers. The inlet vent was of various shapes and sizes, while the outlet vent of the dryers was of the same size. The dryer had sawdust as its insulation material at the base and beneath the collector and the drying chamber of known thickness. Glass of $3 \mathrm{~mm}$ thickness was used as transparent cover material. Plywood was used as construction material. The dryer was inclined at an angle due south and optimum slope angle of $8^{\circ}$ from the horizontal plane of the area of study. The length, width and air plenum of the collector section was obtained with respect to literature reviewed on the course of the study. The values were chosen and 40 $\mathrm{cm}$ and $40 \mathrm{~cm}$ for length and width respectively, while the air plenum was $6 \mathrm{~cm}$ as used by Aziz, et. al [8]. All construction work were done at the Department of Agricultural and Bioresources Engineering, Michael Okpara University of Agriculture, Umudike. The dryers were designed on force convection principle. The outlet vents were uniform ( $5 \mathrm{~mm}$ radius).

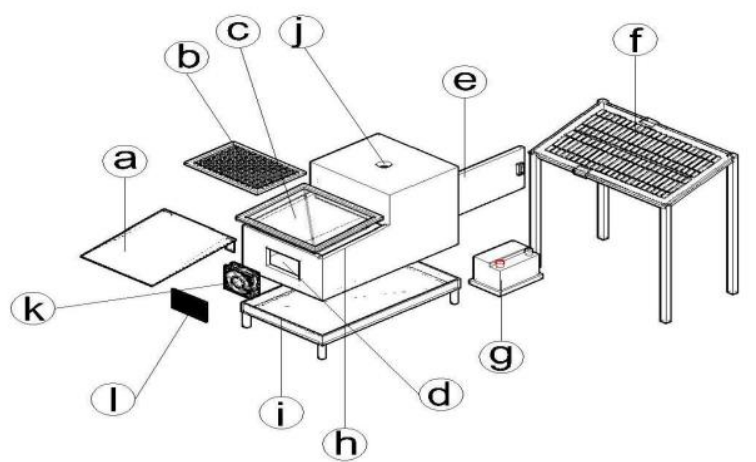

Figure 1: Exploded view of the dryer

\section{Legend:}

A - Absorbent plate

B - Drying tray

C - Transparent cover material

D - Drying chamber

E - Drying chamber lid/door

F - Solar panel

G - D.C. battery

$\mathrm{H}-\quad$ Drying cabin

I - $\quad$ Dryer telescopic leg

J - Blower

Figure 2 shows the constructed dryers displayed in the experimental site.

\subsection{Experimental Design}

The experiment was designed to examine the effect of air inlet duct area on drying time and drying rate of cooking banana. The two independent variables considered were air inlet duct area of the dryer and grater size of the product. The two factors were considered at five levels each using factorial Central Composite Rotatable Design (CCRD), which gave 13 experimental runs, and a total of 52 experimental runs when multiplied with the respective inlet shapes considered (Square, Rectangular, Circular and Triangular). Taheri-Varagand, et. al [17] Used similar design for drying process of banana. For factor 1 (air inlet duct area), the levels were obtained 4, 16, 36, 64 and $100 \mathrm{~cm}^{2}$ for the square shaped inlet, $8,24,40,48$ and $80 \mathrm{~cm}^{2}$ for rectangular air shaped inlet, 3.142 , $12.568,28.278,50.272$ and $78.55 \mathrm{~cm}^{2}$ for circular shaped inlet and $8,16,24,32$ and $40 \mathrm{~cm}^{2}$ for triangular shaped inlet. 


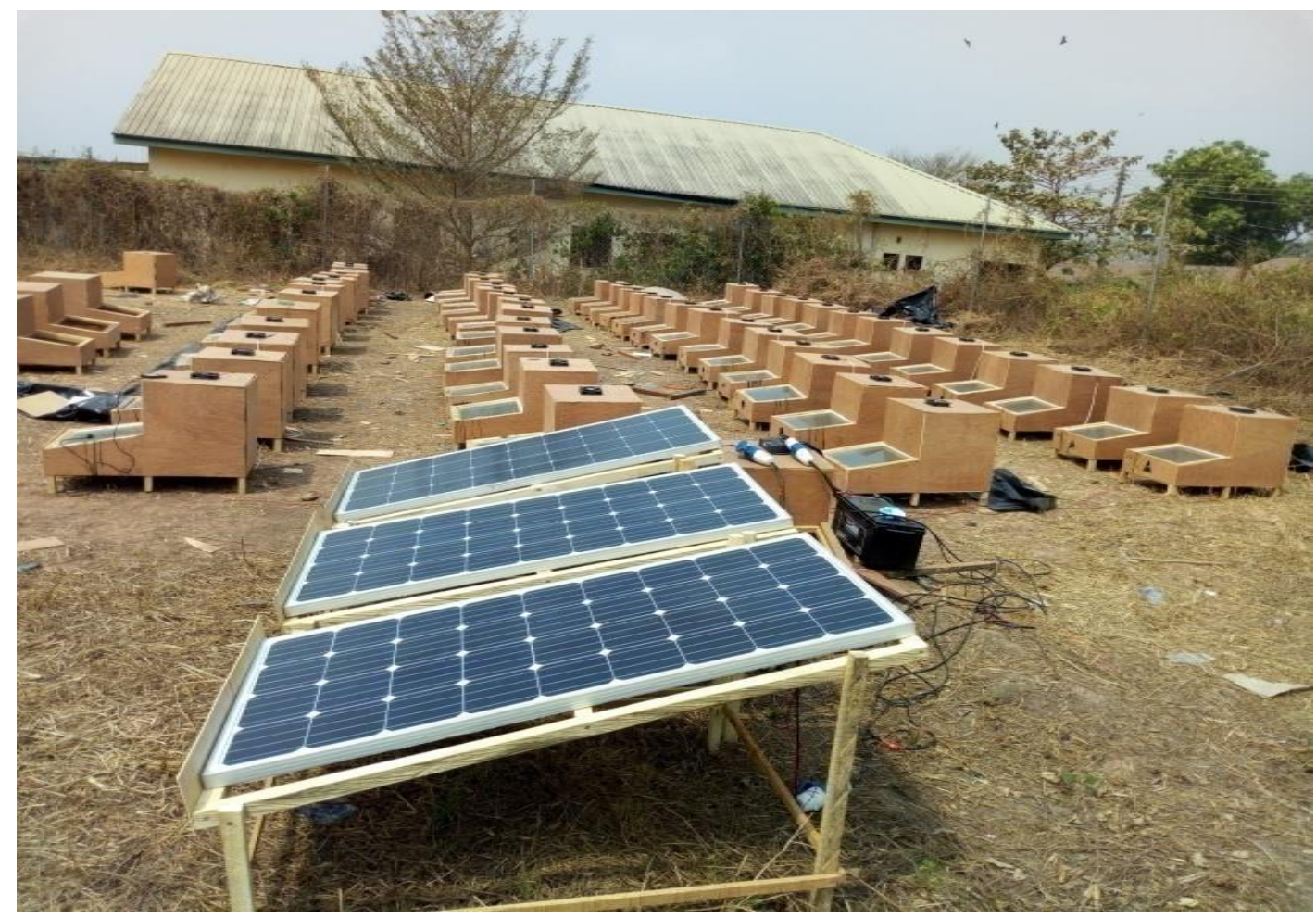

Figure 2: Experimental site

The area was respectively calculated based on the dimensions of the air inlet duct area and use of relevant equation as applicable to the respective shape orientations. For factor 2 (grater size), the levels of were selected as $4\left(P_{1}\right), 8\left(P_{2}\right), 12\left(P_{3}\right), 16\left(P_{4}\right)$ and 20 $\mathrm{mm}\left(P_{5}\right)$. The variation was necessary because there is no optimum grater size recommended for drying the product.

\subsection{Sample Preparation and Data Collection}

Fresh samples of cooking banana were bought from a local market in Umudike and its environs, where the analyses was done; to ensure location proximity. The samples were pealed, the endocarp washed and grated. The grated products were weighed using an electronic weighing balance (Kerro BL 5002 model, with accuracy $0.01 \mathrm{~g}$ ) and placed on a tray. The trays were positioned in the drying chamber. Open sun drying of the product served as control. The samples were dried in batches of three replicate. Data collection was designed in a manner that readings were taken after every two hours from 8:00am to 6:00pm, daily for each drying batch.

\section{RESULTS AND DISCUSSION 3.1 Drying Time}

The drying time varied with respect to the different grater sizes and air inlet duct area. The table 1 show the drying time of the control experiment for the various grater sizes. The drying rate of the product with respect to the air inlet duct area and product size is captured in Table 2.

Table 1: Drying time for open sun (control)

\begin{tabular}{cc}
\hline Grater Size $(\mathrm{mm})$ & Time (Hours) \\
\hline $\mathrm{P}_{1}(4)$ & 15 \\
$\mathrm{P}_{2}(8)$ & 22 \\
$\mathrm{P}_{3}(12)$ & 25 \\
$\mathrm{P}_{4}(16)$ & 30 \\
$\mathrm{P}_{5}(20)$ & 37 \\
\hline
\end{tabular}

Table 2: Summary of drying time, grater size and air

\begin{tabular}{ccccc}
\hline $\begin{array}{c}\text { inlet duct area } \\
\text { Dryer }\end{array}$ & $\begin{array}{c}\text { Shape of } \\
\text { Inlet }\end{array}$ & $\begin{array}{c}\text { Air Inlet } \\
\text { Area }\left(\mathrm{cm}^{2}\right)\end{array}$ & $\begin{array}{c}\text { Product } \\
\text { Size } \\
(\mathrm{mm})\end{array}$ & $\begin{array}{c}\text { Drying } \\
\text { Time } \\
\text { (Hours) }\end{array}$ \\
\hline 1 & Square & $\mathrm{S}_{1}(4)$ & 12 & 17 \\
2 & Square & $\mathrm{S}_{2}(16)$ & 8 & 12 \\
3 & Square & $\mathrm{S}_{2}(16)$ & 12 & 18 \\
4 & Square & $\mathrm{S}_{3}(36)$ & 4 & 9 \\
5 & Square & $\mathrm{S}_{3}(36)$ & 12 & 18 \\
6 & Square & $\mathrm{S}_{3}(36)$ & 12 & 15 \\
7 & Square & $\mathrm{S}_{3}(36)$ & 12 & 17 \\
8 & Square & $\mathrm{S}_{3}(36)$ & 12 & 17
\end{tabular}




\begin{tabular}{|c|c|c|c|c|}
\hline $\begin{array}{l}\text { Dryer } \\
\text { Number }\end{array}$ & $\begin{array}{l}\text { Shape of } \\
\text { Inlet }\end{array}$ & $\begin{array}{c}\text { Air Inlet } \\
\text { Area }\left(\mathrm{cm}^{2}\right)\end{array}$ & $\begin{array}{c}\text { Product } \\
\text { Size } \\
(\mathrm{mm})\end{array}$ & $\begin{array}{c}\text { Drying } \\
\text { Time } \\
\text { (Hours) }\end{array}$ \\
\hline 9 & Square & $\mathrm{S}_{3}(36)$ & 12 & 16 \\
\hline 10 & Square & $\mathrm{S}_{3}(36)$ & 20 & 23 \\
\hline 11 & Square & $\mathrm{S}_{4}(64)$ & 8 & 14 \\
\hline 12 & Square & $\mathrm{S}_{4}(64)$ & 16 & 20 \\
\hline 13 & Square & $S_{5}(100)$ & 12 & 17 \\
\hline 14 & Rectangular & $R_{1}(8)$ & 12 & 19 \\
\hline 15 & Rectangular & $\mathrm{R}_{2}(24)$ & 8 & 13 \\
\hline 16 & Rectangular & $\mathrm{R}_{2}(24)$ & 12 & 19 \\
\hline 17 & Rectangular & $\mathrm{R}_{3}(48)$ & 4 & 10 \\
\hline 18 & Rectangular & $\mathrm{R}_{3}(48)$ & 12 & 18 \\
\hline 19 & Rectangular & $\mathrm{R}_{3}(48)$ & 12 & 17 \\
\hline 20 & Rectangular & $R_{3}(48)$ & 12 & 17 \\
\hline 21 & Rectangular & $\mathrm{R}_{3}(48)$ & 12 & 18 \\
\hline 22 & Rectangular & $R_{3}(48)$ & 12 & 16 \\
\hline 23 & Rectangular & $\mathrm{R}_{3}(48)$ & 20 & 26 \\
\hline 24 & Rectangular & $\mathrm{R}_{4}(80)$ & 8 & 13 \\
\hline 25 & Rectangular & $\mathrm{R}_{4}(80)$ & 16 & 23 \\
\hline 26 & Rectangular & $\mathrm{R}_{5}(40)$ & 12 & 20 \\
\hline 27 & Circular & $C_{1}(3.142)$ & 12 & 17 \\
\hline 28 & Circular & $C_{2}(12.568)$ & 8 & 13 \\
\hline 29 & Circular & $\mathrm{C}_{2}(12.568)$ & 12 & 19 \\
\hline 30 & Circular & $\mathrm{C}_{3}(28.278)$ & 4 & 11 \\
\hline 31 & Circular & $\mathrm{C}_{3}(28.278)$ & 12 & 18 \\
\hline 32 & Circular & $\mathrm{C}_{3}(28.278)$ & 12 & 17 \\
\hline 33 & Circular & $\mathrm{C}_{3}(28.278)$ & 12 & 17 \\
\hline 34 & Circular & $\mathrm{C}_{3}(28.278)$ & 12 & 18 \\
\hline 35 & Circular & $\mathrm{C}_{3}(28.278)$ & 12 & 18 \\
\hline 36 & Circular & $\mathrm{C}_{3}(28.278)$ & 20 & 26 \\
\hline 37 & Circular & $\mathrm{C}_{4}(50.272)$ & 8 & 14 \\
\hline 38 & Circular & $\mathrm{C}_{4}(50.272)$ & 16 & 21 \\
\hline 39 & Circular & $\mathrm{C}_{5}(78.55)$ & 12 & 19 \\
\hline 40 & Triangular & $\mathrm{T}_{1}(8)$ & 12 & 16 \\
\hline 41 & Triangular & $\mathrm{T}_{2}(16)$ & 8 & 13 \\
\hline 42 & Triangular & $\mathrm{T}_{2}(16)$ & 12 & 16 \\
\hline 43 & Triangular & $\mathrm{T}_{3}(24)$ & 4 & 9 \\
\hline 44 & Triangular & $\mathrm{T}_{3}(24)$ & 12 & 16 \\
\hline 45 & Triangular & $\mathrm{T}_{3}(24)$ & 12 & 15 \\
\hline 46 & Triangular & $\mathrm{T}_{3}(24)$ & 12 & 16 \\
\hline 47 & Triangular & $\mathrm{T}_{3}(24)$ & 12 & 16 \\
\hline 48 & Triangular & $\mathrm{T}_{3}(24)$ & 12 & 15 \\
\hline 49 & Triangular & $\mathrm{T}_{3}(24)$ & 20 & 25 \\
\hline 50 & Triangular & $\mathrm{T}_{4}(32)$ & 8 & 12 \\
\hline 51 & Triangular & $T_{4}(32)$ & 16 & 21 \\
\hline 52 & Triangular & $T_{5}(40)$ & 12 & 16 \\
\hline
\end{tabular}

From the table, for products of grater size $\mathrm{P}_{1}(4 \mathrm{~mm})$, drying was achieved in an average of 10 hours, as against 15 hours it took to get the same product of equal grater size dried on open sun. About $35 \%$ of the drying time was conserved. The dryer with the least time of drying ( 9 hours) had an air inlet duct area of $36 \mathrm{~cm}^{2}$. For products of grater size $P_{2}(8 \mathrm{~mm})$, the products were observed to have dried between 12 to 14 hours. In comparison with the control, about $41 \%$ of the drying time was saved in the process. For products of grater size $P_{3}(12 \mathrm{~mm})$, drying was achieved on an average of 16 hours, as compared to open dun drying (25 hours). Similar trend was observed for grater size $\mathrm{P}_{4}(16 \mathrm{~mm})$, and $\mathrm{P}_{5}(20 \mathrm{~mm})$ respectively, as they showed more than $30 \%$ variation when compared to open sun drying. The results obtained were quite close to what was obtained by Umoh and Garba [19] for some selected crops in Kano, Nigeria. Wakjira, et. a/[20] developed a solar dryer for banana and considered the air inlet duct area as 25 $\mathrm{cm}^{2}$, and achieved drying between 4 to 5 days for grater size range of 1 to $6 \mathrm{~mm}$. These findings were quite dissimilar to what was obtained in the study. The variation could be traced to the nature of the dryer and feature, as the former was a passive solar dryer.

\subsection{Drying Rate}

For open sun drying which served as control, the drying rates of the products were obtained as in Table 3.

Table 3: Drying rate of control

\begin{tabular}{cl}
\hline Grater Size $(\mathrm{mm})$ & Drying Rate $(\mathrm{g} / \mathrm{hr})$ \\
\hline $\mathrm{P}_{1}(4)$ & 1.48 \\
$\mathrm{P}_{2}(8)$ & 1.88 \\
$\mathrm{P}_{3}(12)$ & 2.31 \\
$\mathrm{P}_{4}(16)$ & 2.74 \\
$\mathrm{P}_{5}(20)$ & 2.89 \\
\hline
\end{tabular}

The drying rates of products in the dryer with respect to air inlet duct area and product size are as given in Table 4.

Table 4: Drying rate of products dried in the respective dryers

\begin{tabular}{ccccc}
\hline $\begin{array}{c}\text { Dryer } \\
\text { Number }\end{array}$ & $\begin{array}{c}\text { Shape of } \\
\text { Inlet }\end{array}$ & $\begin{array}{c}\text { Air Inlet } \\
\text { Area }\left(\mathrm{cm}^{2}\right)\end{array}$ & $\begin{array}{c}\text { Product } \\
\text { Size } \\
(\mathrm{mm})\end{array}$ & $\begin{array}{c}\text { Drying } \\
\text { Rate } \\
(\mathrm{g} / \mathrm{hr})\end{array}$ \\
\hline 1 & Square & $\mathrm{S}_{1}(4)$ & 12 & 3.12 \\
2 & Square & $\mathrm{S}_{2}(16)$ & 8 & 3.19 \\
3 & Square & $\mathrm{S}_{2}(16)$ & 12 & 3.16 \\
4 & Square & $\mathrm{S}_{3}(36)$ & 4 & 2.46 \\
5 & Square & $\mathrm{S}_{3}(36)$ & 12 & 3.12 \\
6 & Square & $\mathrm{S}_{3}(36)$ & 12 & 3.88 \\
7 & Square & $\mathrm{S}_{3}(36)$ & 12 & 3.11 \\
8 & Square & $\mathrm{S}_{3}(36)$ & 12 & 3.14 \\
9 & Square & $\mathrm{S}_{3}(36)$ & 12 & 3.32 \\
10 & Square & $\mathrm{S}_{3}(36)$ & 20 & 3.99 \\
11 & Square & $\mathrm{S}_{4}(64)$ & 8 & 3.02 \\
12 & Square & $\mathrm{S}_{4}(64)$ & 16 & 3.78 \\
13 & Square & $\mathrm{S}_{5}(100)$ & 12 & 3.49 \\
14 & Rectangular & $\mathrm{R}_{1}(8)$ & 12 & 2.85 \\
15 & Rectangular & $\mathrm{R}_{2}(24)$ & 8 & 2.99 \\
16 & Rectangular & $\mathrm{R}_{2}(24)$ & 12 & 3.03 \\
17 & Rectangular & $\mathrm{R}_{3}(48)$ & 4 & 2.19 \\
18 & Rectangular & $\mathrm{R}_{3}(48)$ & 12 & 2.94
\end{tabular}




\begin{tabular}{|c|c|c|c|c|}
\hline $\begin{array}{c}\text { Dryer } \\
\text { Number }\end{array}$ & $\begin{array}{c}\text { Shape of } \\
\text { Inlet }\end{array}$ & $\begin{array}{c}\text { Air Inlet } \\
\text { Area }\left(\mathrm{cm}^{2}\right)\end{array}$ & $\begin{array}{c}\text { Product } \\
\text { Size } \\
(\mathrm{mm})\end{array}$ & $\begin{array}{l}\text { Drying } \\
\text { Rate } \\
(\mathrm{g} / \mathrm{hr})\end{array}$ \\
\hline 19 & Rectangular & $\mathrm{R}_{3}(48)$ & 12 & 3.20 \\
\hline 20 & Rectangular & $\mathrm{R}_{3}(48)$ & 12 & 3.10 \\
\hline 21 & Rectangular & $\mathrm{R}_{3}(48)$ & 12 & 3.36 \\
\hline 22 & Rectangular & $\mathrm{R}_{3}(48)$ & 12 & 3.38 \\
\hline 23 & Rectangular & $\mathrm{R}_{3}(48)$ & 20 & 3.84 \\
\hline 24 & Rectangular & $\mathrm{R}_{4}(80)$ & 8 & 3.01 \\
\hline 25 & Rectangular & $\mathrm{R}_{4}(80)$ & 16 & 3.44 \\
\hline 6 & Rectangular & $\mathrm{R}_{5}(40)$ & 12 & 2.63 \\
\hline 27 & Circular & $\mathrm{C}_{1}(3.142)$ & 12 & 3.13 \\
\hline 28 & Circular & $\mathrm{C}_{2}(12.568)$ & 8 & 2.98 \\
\hline 29 & Circular & $\mathrm{C}_{2}(12.568)$ & 12 & 2.75 \\
\hline 30 & Circular & $\mathrm{C}_{3}(28.278)$ & 4 & 1.95 \\
\hline 31 & Circular & $\mathrm{C}_{3}(28.278)$ & 12 & 2.97 \\
\hline 32 & Circular & $\mathrm{C}_{3}(28.278)$ & 12 & 3.10 \\
\hline 33 & Circular & $\mathrm{C}_{3}(28.278)$ & 12 & 3.12 \\
\hline 34 & Circular & $\mathrm{C}_{3}(28.278)$ & 12 & 2.87 \\
\hline 35 & Circular & $\mathrm{C}_{3}(28.278)$ & 12 & 3.02 \\
\hline 36 & Circular & $\mathrm{C}_{3}(28.278)$ & 20 & 3.77 \\
\hline 37 & Circular & $\mathrm{C}_{4}(50.272)$ & 8 & 2.91 \\
\hline 38 & Circular & $\mathrm{C}_{4}(50.272)$ & 16 & 3.64 \\
\hline 39 & Circular & $\mathrm{C}_{5}(78.55)$ & 12 & 2.91 \\
\hline 40 & Triangular & $\mathrm{T}_{1}(8)$ & 12 & 3.74 \\
\hline 41 & Triangular & $\mathrm{T}_{2}(16)$ & 8 & 3.18 \\
\hline 42 & Triangular & $\mathrm{T}_{2}(16)$ & 12 & 3.35 \\
\hline 43 & Triangular & $\mathrm{T}_{3}(24)$ & 4 & 2.44 \\
\hline 44 & Triangular & $\mathrm{T}_{3}(24)$ & 12 & 3.33 \\
\hline 45 & Triangular & $\mathrm{T}_{3}(24)$ & 12 & 3.64 \\
\hline 46 & Triangular & $\mathrm{T}_{3}(24)$ & 12 & 3.36 \\
\hline 47 & Triangular & $\mathrm{T}_{3}(24)$ & 12 & 3.32 \\
\hline
\end{tabular}

\begin{tabular}{ccccc}
\hline $\begin{array}{c}\text { Dryer } \\
\text { Number }\end{array}$ & $\begin{array}{c}\text { Shape of } \\
\text { Inlet }\end{array}$ & $\begin{array}{c}\text { Air Inlet } \\
\text { Area }\left(\mathrm{cm}^{2}\right)\end{array}$ & $\begin{array}{c}\text { Product } \\
\text { Size } \\
(\mathrm{mm})\end{array}$ & $\begin{array}{c}\text { Drying } \\
\text { Rate } \\
(\mathrm{g} / \mathrm{hr})\end{array}$ \\
\hline 48 & Triangular & $\mathrm{T}_{3}(24)$ & 12 & 2.24 \\
49 & Triangular & $\mathrm{T}_{3}(24)$ & 20 & 3.93 \\
50 & Triangular & $\mathrm{T}_{4}(32)$ & 8 & 3.26 \\
51 & Triangular & $\mathrm{T}_{4}(32)$ & 16 & 3.55 \\
52 & Triangular & $\mathrm{T}_{5}(40)$ & 12 & 3.47 \\
\hline
\end{tabular}

From the tables, product of grater size $\mathrm{P}_{1}(4 \mathrm{~mm})$, averagely had a drying rate of $2.52 \mathrm{~g} / \mathrm{hr}$, as against $1.48 \mathrm{~g}$ obtained for the control experiment of the same grater size. There was a variation of $42 \%$, in comparing the two processes. Similar trend was recorded for $\mathrm{P}_{2}(8 \mathrm{~mm})$, and $\mathrm{P}_{3}(12 \mathrm{~mm})$, respectively, as the drying rates showed about $40 \%$ variation. The air inlet duct area corresponding to the grater sizes, were between 16 and $100 \mathrm{~cm}^{2}$. The average drying rate of $\mathrm{P}_{4}(16 \mathrm{~mm})$ and $\mathrm{P}_{5}(20 \mathrm{~mm})$, recorded a variation of $30 \%$, when comparing their drying rates with open sun drying. Similar trend was reported by Irtwange, and Adeboye [11] for corn. Figure 3 shows variation in drying rate with air inlet area and product size for various air inlet shapes.

Analysis of variance of the drying rate of the product in the respective inlet shape orientation is given in Tables 5 to 8 .

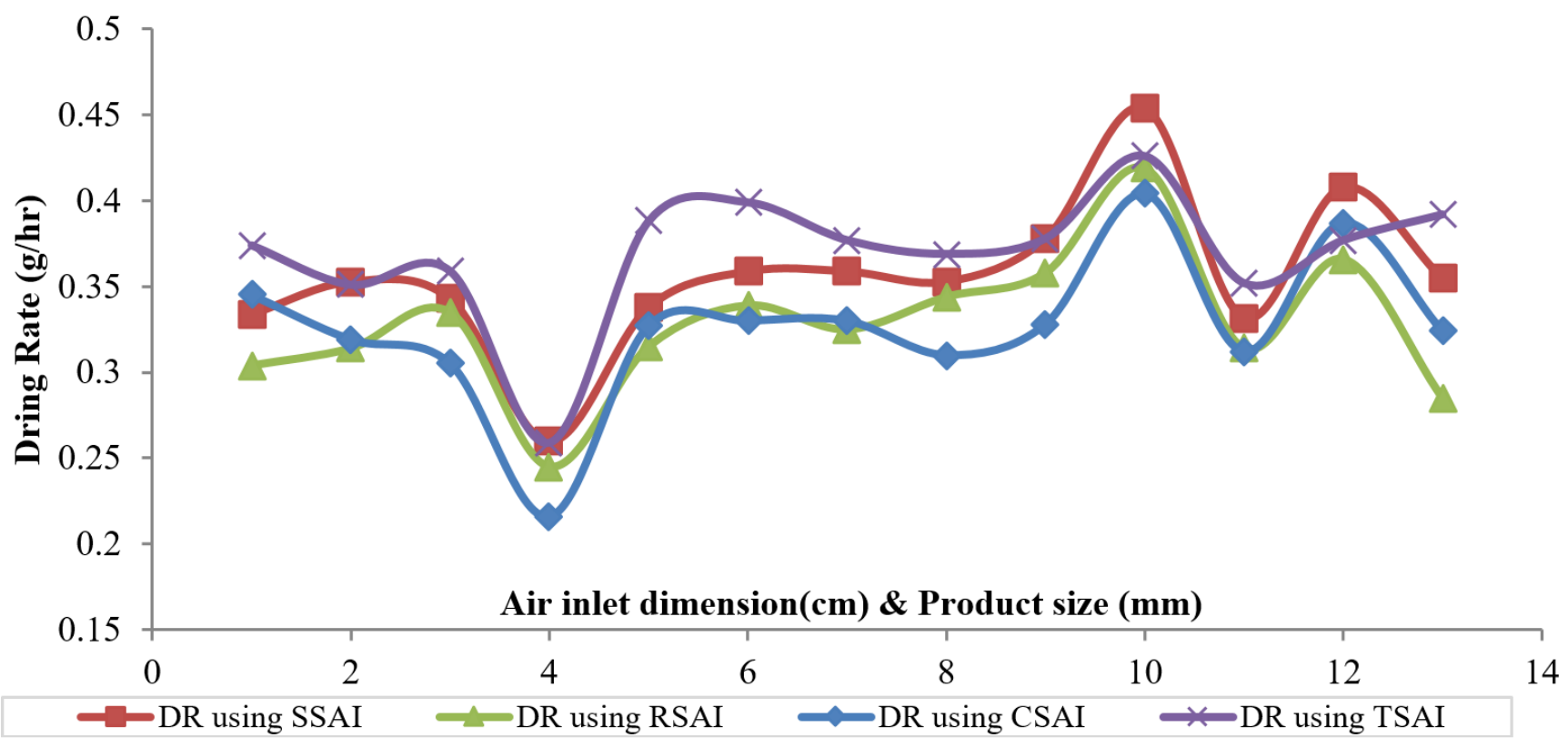

Figure 3: Variation in drying rate with air inlet dimension and product size for various air inlet shapes.

Where: SSAI is Square Shape Air Inlet; RSAI is Rectangular Shape Air Inlet

CSAI is Circular Shape Air Inlet; TSAI is Triangular Shape Air Inlet 
Table 5: Analysis of Variance for drying rate for square shape air inlet

\begin{tabular}{llllll}
\hline Source & Sum of Square & df & Mean Square & F-Value & P-Value \\
\hline Air Inlet Dimensions $(\mathrm{cm})$ & 0.1180 & 1 & 0.11801 & 1.67 & 0.225 \\
Product Size $(\mathrm{mm})$ & 1.1970 & 1 & 1.19701 & 16.97 & 0.002 \\
Error & 0.7055 & 10 & 0.07055 & & \\
Total & 2.0205 & 12 & & & \\
\hline
\end{tabular}

Table 6: Analysis of Variance for drying rate for rectangular shape air inlet

\begin{tabular}{llllll}
\hline Source & Sum of Square & df & Mean Square & F-Value & P-Value \\
\hline Air Inlet Dimensions $(\mathrm{cm})$ & 0.00001 & 1 & 0.00001 & 0.00 & 0.992 \\
Product Size $(\mathrm{mm})$ & 1.18441 & 1 & 1.18441 & 15.03 & 0.003 \\
Error & 0.78809 & 10 & 0.07881 & & \\
Total & 1.97251 & 12 & & & \\
\hline
\end{tabular}

Table 7: Analysis of Variance for drying rate for circular shape air inlet

\begin{tabular}{llllll}
\hline Source & Sum of Square & df & Mean Square & F-Value & P-Value \\
\hline Air Inlet Dimensions $(\mathrm{cm})$ & 0.01203 & 1 & 0.01203 & 0.15 & 0.707 \\
Product Size $(\mathrm{mm})$ & 1.42830 & 1 & 1.42830 & 17.81 & 0.002 \\
Error & 0.80216 & 10 & 0.08022 & & \\
Total & 2.24249 & 12 & & & \\
\hline
\end{tabular}

Table 8: Analysis of Variance for drying rate for triangular shape air inlet

\begin{tabular}{llllll}
\hline Source & Sum of Square & df & Mean Square & F-Value & P-Value \\
\hline Air Inlet Dimensions $(\mathrm{cm})$ & 0.00563 & 1 & 0.005633 & 0.03 & 0.859 \\
Product Size $(\mathrm{mm})$ & 0.98613 & 1 & 0.986133 & 5.83 & 0.036 \\
Error & 1.69171 & 10 & 0.169171 & & \\
Total & 2.68348 & 12 & & & \\
\hline
\end{tabular}

From the Tables, the air inlet duct area had significant effect on the drying rate of the product at $5 \%$ level of significance, since all $p$-values obtained were higher than 0.05 . On the contrary, the grater size had no significant effect on the drying rate, since all its $p$ values were less than the desired probability level.

\section{CONCLUSIONS AND RECOMMENDATIONS}

The air inlet duct area of the dryers had effect on the drying time of the products. Drying was achieved within 9 to 26 hours (depending on the respective grater sizes) as against open sun, which drying was achieved between 15 to 37 hours. The dryers conserved between 26.67 to $37.84 \%$ of the drying time. The drying rate of the products increased from 2.24 to $3.93 \mathrm{~g} / \mathrm{hr}$. There was a reported variation of between the field experiment and the control was averagely $36 \%$. The air inlet duct area had significant effect on the drying rate of the product at $5 \%$ level of significance, while the grater size had no significant effect on the drying rate of the product. It is recommended that the air inlet duct area of the dryer and grater size of the product be optimized, to ascertain the conditions that will give more optimum drying of the product.

\section{REFERENCES}

[1] Abano, E. E., Ma, H. and Qu, W. Optimization of drying conditions of quality dried tomato slices. Journal of food processing and preservation, 38(3), pp. 212-221, 2012.

[2] Adeniji, T. A., Tenkouano, A., Ezurike J. N., Ariyo, C. O. and Vroh-Bi, I. Value-adding postharvest processing of cooking bananas (Musa spp. ABB and ABB genome groups). African Journal of Biotechnology, 9 (54), pp. 9135 9141, 2010. 
[3] Alamu, A. H. Experiments on Aluminum Copper Alloys Properties as Solar absorbers. JJMIE, 4(6), pp. 86-90, 2010.

[4] Alonge, A. F. and Adeboye, O. A. Drying rates of some fruits and vegetables with passive solar dryers. International Journal of Agricultural and Biological Engineering, 5(4), pp.83-92, 2012.

[5] Alonge, A. F. and Jackson, N. I. Development of an Indirect Forced Convection Solar Dryer for Cassava Chips. Journal of Agricultural Engineering and Technology, 22(4), pp.89-100, 2014.

[6] Alonge, A. F. and Oniya O. O. An indirect passive solar dryer for drying. Advanced Materials Research, 36 (12), pp 517 - 524, 2012.

[7] ASABE. American Society of Agricultural and Biological Engineers Standards. 2010.

[8] Aziz, A., Rehman, S. U. and Rehman, S. U. Exergy Analysis of Solar Cabinet Dryer and Evaluate the Performance Enhancement of Solar Cabinet Dryer by Addition of Solar Reflectors. International Journal of Renewable Energy Research, 6(4), pp. 1396-1402, 2016.

[9] Eke, A. B. Evaluation of Polythene as Solar Thermal Collector Top Cover. Journal of Sustainable Agriculture and Environment, 15(1), pp. 167-178, 2014.

[10] Ikejiofor M. C. and Okonkwo W. I. Design and Development of an Active Solar Dryer with Adjustable Air Flow Rates for Agricultural Products. Journal of Agricultural Engineering and Technology, 18(2), pp.70-76, 2010.

[11] Irtwange S. V. and Adebayo, S. Development and performance of a laboratory scale passive solar grain dryer in a tropical environment. Journal of Agricultural Engineering and rural development, 1 (2), pp. 42-49, 2009.

[12] Itodo, I. N., Adewole, A. M. and Edamaku, S. K. Development of an active solar crop dryer. Design analysis and performance evaluation. Journal of Food Science and Technology, 41(1), pp. 37-42, 2004.
[13] Oguntola, J. A., Colins, N. N., Olayinka, A. Design and construction of a domestics passive solar food dryer. Lenardo Journal of Science, (16) 1 , pp. 23-30., 2010.

[14] Onyinye, G. O., Oduor, A. O. and Othieno, H. E. The design and testing of an indirect cabinet solar dryer for thin drying of Rastrineobola Argentea fish under the climatic conditions of Maseno, Kenya. African Journal of Food Science, 9(1), pp.1-16, 2015.

[15] Raju, R.V.S, Really R. M. and Reddy, E. S. Design and fabrication of efficient solar dryer. International Journal of Engineering Research and Applications, 3(6), pp. 1445-1458, 2015.

[16] Sacilik, K. Effect of drying methods on thin-layer drying characteristics of hull-less seed pumpkin. Journal of food Engineering, 79 (1), pp. 23-30, 2007.

[17] Taheri-Garavand, A., Karimi, F., Karimi, M., Lofti, V. and Khoobbakht, G. Hybrid response surface methodology - artificial neural network optimization of drying process of banana slices in a forced convective dryer. Food Science and Technology International, 24(4), pp. 277-291, 2017.

[18] Tonui, K. S., Mutai, E. B. K., Mbuge, D. O. and Too, K. V. Design and evaluation of a solar grain dryer with a backup heater. Research Journal of Applied Sciences, Engineering and Technology, 1(1), pp. 2-8, 2014.

[19] Umoh, I. and Garba, I. Design, construction and experimental evaluation of a double slope solar dryer in kano, Nigeria. The international Journal of Engineering and science, 2 (9), pp. 26-35, 2013.

[20] Wakjira, M., Adunga, D. and Berecha, G. Determining slice thickness of Banana (Musa 5pp) for enclosed solar drying using solar cabinet dryer under Ethiopian conditions. African Journal of Food Technology, 6 (1), pp. 568-580, 2011. 